\title{
PERUBAHAN PILIHAN SANTRI GRESIK PADA PILPRES 2019
}

\author{
Avita Amelia1, Dwi Krismawati², Moch Aji Setiawan³, Retno Aprin Cahyani4, Husna \\ Suhada $^{5}$, Agus Machfud Fauzi ${ }^{6}$ \\ ${ }^{1}$ Fakultas Ilmu Sosial Hukum, Universitas Negeri Surabaya \\ korespondensi email: avita.17040564027@mhs.unesa.ac.id \\ ${ }^{2}$ Fakultas Ilmu Sosial Hukum, Universitas Negeri Surabaya \\ email: dwi.17040564005@mhs.unesa.ac.id \\ ${ }^{3}$ Fakultas Ilmu Sosial Hukum, Universitas Negeri Surabaya \\ email: moch.17040564008@mhs.unesa.ac.id \\ ${ }^{4}$ Fakultas Ilmu Sosial Hukum, Universitas Negeri Surabaya \\ email: retno.17040564020@mhs.unesa.ac.id \\ ${ }^{5}$ Fakultas Ilmu Sosial Hukum, Universitas Negeri Surabaya \\ email: husna.17040564035@mhs.unesa.ac.id \\ ${ }_{6}^{6}$ Fakultas Ilmu Sosial Hukum, Universitas Negeri Surabaya \\ email: agusmfauzi@unesa.ac.id
}

\begin{abstract}
Indonesia is a country that has a presidential government system with the president and deputy as the country's leaders. The head of state is responsible for regulating and establishing state policies for the better. The existence of a president and his deputy is elected through an election process. The presidential election in each region is certainly different from the various interesting phenomena in it such as in Gresik, which is famous for the nickname of the city of Santri. The purpose of this study was to determine the students' motives in Gresik in the presidential election in 2019. That is because in the 2014 presidential election in the Gresik region, Prabowo's candidate won a victory. However, in the 2019 presidential election Jokowi's candidate was the winner. The research method used in this research is descriptive qualitative. The research subjects in this study were students in the city of Gresik. Data collection instruments used in this study were in-depth interviews, literature study, and observation. The results of this study indicate that the voice change that occurred in the 2019 presidential election was due to the large influence of the vice president who was promoted by the Jokowi camp, Ma'ruf Amin because, it became a big consideration for the students in making choices. In addition, as Nahdliyin students there is a tradition in Islamic boarding schools to be obedient to their kiai.
\end{abstract}

Keyword: vote changing; santri; presidential couple.

\begin{abstract}
ABSTRAK
Indonesia merupakan negara yang memiliki sistem pemerintahan presidensial dengan presiden dan wakilnya sebagai pemimpin negara. Kepala negara bertanggung jawab untuk mengatur dan menetapkan kebijakan negara agar menjadi lebih baik. Adanya presiden dan wakilnya tersebut dipilih melalui proses pemilihan. Pemilihan presiden disetiap wilayah tentunya berbeda dengan beragam fenomena menarik didalamnya seperti di Gresik yang terkenal dengan julukan kota Santri. Tujuan dari penelitian ini untuk mengetahui motif santri Gresik dalam pemilihan presiden pada tahun 2019. Hal tersebut dikarenakan pada pilpres 2014 di wilayah Gresik, paslon Prabowo memperoleh kemenangan. Namun, pada pilpres 2019 paslon Jokowi yang menjadi pemenang. Metode penelitian yang digunakan
\end{abstract}


pada penelitian ini yaitu kualitatif deskriptif. Subjek penelitian dalam penelitian ini adalah santri di kota Gresik. Instrument pengumpulan data yang digunakan dalam penelitian ini yakni indepth interview, studi pustaka, dan observasi. Hasil penelitian ini menunjukkan bahwa perubahan suara yang terjadi pada pilpres 2019 disebabkan oleh besarnya pengaruh dari wakil presiden yang diusung kubu Jokowi yakni Ma'ruf Amin karena, menjadi pertimbangan besar bagi para santri dalam menentukan pilihan. Di samping itu, sebagai santri Nahdliyin terdapat tradisi dalam pondok pesantren untuk patuh terhadap kiainya.

Kata Kunci: perubahan suara; santri; pasangan presiden.

\section{PENDAHULUAN}

Indonesia merupakan negara dengan sistem pemerintahan presidensial terlihat dari presiden dan wakilnya sebagai pemimpin negara. Presiden dan wakilnya dipilih melalui proses pemilihan presiden, yang dilaksanakan setiap lima tahun sekali (Susilo \& Roesli, 2018); (Santoso, 2013). Di samping itu, dalam pemilihan tersebut selalu berdampingan dengan kampanye untuk menggiring suara rakyat dan memperoleh simpatinya. Masyarakat pun juga ikut andil dalam memilih pemimpin sesuai keinginan mereka. Berbicara mengenai pemilu maka, yang akan menjadi sorotan utama adalah calon presiden. Seperti halnya calon presiden Indonesia didua periode terakhir masih sama yaitu, kubu Jokowi dan Prabowo hanya berbeda wakilnya saja (Aziz, 2018).

Pada saat pemiliu tahun 2014 kubu Jokowi memenangkan suara atas Prabowo sebesar 53,15\%. Sedangkan, Prabowo hanya memperoleh vote sebesar 46.85\%. Pada tahun 2019 seperti mengulang nostalgia yang sama kedua pemimpin ini kembali mencalonkan diri menjadi kandidat presiden hanya berbeda wakil saja, kubu Jokowi memilih wakil seorang tokoh agama yakni Ma'ruf Amin. Berbeda halnya dengan kubu Prabowo memilih pasangan wakilnya dari idola kaum milenial dan ibu-ibu masa kini yakni Sandiaga Uno. Keduanya bersaing ketat untuk memperebutkan suara hati para masyarakat. Banyak tempat yang mereka datangi untuk menarik simpati para pemilih diantaranya adalah Gresik yang berada didaerah Jawa Timur. Pada tahun sebelumnya Prabowo berhasil menjadikan Gresik sebagai lumbung suara hingga dapat meraih suara kemenangan sebanyak $52.90 \%$.

Sedangkan, kubu Jokowi hanya bisa memperoleh 47.10\% suara. Oleh karena itu, hal ini menjadi sangat menarik untuk dikaji dikarenakan, pada pilpres 2019 Gresik yang diunggulkan diperiode sebelumnya oleh kubu Prabowo, justru berbalik menjadi milik Jokowi. Terlebih lagi, setelah munculnya tagar \#Jokowi 2 periode sebagai bentuk perlawanan terhadap calon presiden Prabowo (Fauzi Agus, 2019) membuat persaingan semakin sengit. Disinilah timbul permasalahan terkait dengan perubahan suara yang terjadi di Gresik. Seperti yang diketahui bahwa Gresik tidak hanya dikenal sebagai kota industri tetapi juga kota santri. Hal tersebut didasarkan pada misinya untuk meningkatkan nilai keagamaan dalam kehidupan bermasyarakat. Artinya, untuk mewujudkan warga Gresik yang santun dan berbudi pekerti luhur.

Terkait dengan pernyataan tersebut di Gresik pun terdapat banyak pondok pesantren. Tentunya dengan para santri berkualitas yang menjadi kebanggaan Gresik. Gresik sebagai kota santri tersebut tentunya mempengaruhi kultur keagamaan dan aspek lainnya di Gresik. Oleh karena itu, pilpres 2019 kemarin Gresik menjadi salah satu kota yang mendapat perhatian masyarakat. Hal tersebut tidak terlepas dari peranan Ma'ruf Amin sebagai kandidat wakil presiden waktu itu. Seperti yang kita lihat bahwasanya Ma'ruf memiliki latar belakang sebagai ulama. Berangkat dari pemaparan latar belakang diatas bagaimana bisa terjadinya perubahan pilihan santri Gresik pada pilpres 2019. 


\section{TINJAUAN PUSTAKA}

Mekanisme pemilihan presiden dan wakilnya dilaksanakan sesuai dengan perkembangan zaman. Hal tersebut dikarenakan dunia akan selalu berkembang dan memungkinkan untuk terjadinya perubahan. Di setiap perubahan yang terjadi pasti memiliki perbedaan antara zaman dulu dengan sekarang. Oleh karena itu, pedoman yang dijadikan dalam pelaksanaan pemilihan pemimpin negara yakni menyesuaikan dengan kebutuhan zaman saat ini (Wulandari, 2017). Di samping itu, dalam pelaksanaan pemilihan kepala negara selalui diwarnai dengan berbagai hal yang menarik. Misalnya, keraguan publik di Bandar Lampung terhadap suara NU pada pilres 2019 karena, faktor historis. Hal tersebut dikarenakan pada pilpres 2004 saat itu, Hasyim Muzadi dan Salahudin Wahid mengalami kekalahan karena, tidak solidnya struktural dan kultural dalam tubuh NU. Di sisi lain, NU Bandar Lampung adalah cabang tertua di Lampung. Berdiri sejak tahun 1964 dengan keunikan warganya yang heterogen. Mereka memilki tipe budaya politik partisipan karena memliki pengetahuan, perasaan, dan penilaian pada seluruh aspek (Ulzikri, 2019).

Di sisi lain, pada pilpres 2019 suara NU mengalami kemenangan seperti di Gresik. Artinya, kegagalan NU pada pilpres 2004 yang lalu tidak terulang kembali. Salah satu faktor penyebab kemenangan NU yakni semakin menguatnya pembentukan politik identitas. Hal tersebut terlihat dari adanya kelompok santri di pesantren yang menjadi sasaran dalam politik (Abidin, 2018). Oleh karena itu, keterlibatan pesantren dalam politik secara nyata telah menimbulkan berbagai dampak yang cukup signifikan. Di samping itu, telah mengukuhkan politik pragmatis karena, menjanjikan kompensasi materi. Kondisi tersebut menyebabkan pesantren jauh dari masyarakat. Hal tersebut semakin terasa ketika masyarakat mulai menyoroti sikap politik pesantren yang dianggap hanya merusak independensi pesantren. Terlebih lagi, juga memecahkan umat ke dalam politik partisipan (Ernas, 2005). Terlihat juga bahwa adanya hubungan antara kiai dan politik. Hal tersebut ditunjukkan pula pada pilpres 2014, bahwa kiai telah menjadikan pesantren sebagai target dalam mencari dukungan politik (Hidayat, 2016). Begitu pula Greetz juga menjelaskan bahwa kiai saat ini tidak hanya sebagai makelar budaya tetapi, makelar politik bahkan aktor politik (Hidayat, 2014). Berkaitan dengan hal tersebut tentunya perlu diketahui motif dari santri dalam memilih calon pemimpin. Berdasarkan pada pengetahuan dan pengalaman yang mereka miliki.

Penelitian ini menggunakan perspektif teori Fenomenologi Alfred Schutz yang memfokuskan pada unsur motif. Ia berpendapat bahwa untuk mengetahui motif individu dalam melakukan suatu tindakan secara pasti itu sangat sulit. Terlebih lagi individu tersebut memiliki persepsi dan pengalaman yang berbeda beda. Oleh karena itu, untuk menjelaskan makna dari tindakan individu yang berdasarkan motif tersebut, diperlukan membuat tahapan historis. Tahapan tersebut seperti yang dipelopori Alfred Schutz, yaitu in order to motive dan because motive. In order to motive artinya lebih mengarah pada masa depan. Berbeda halnya dengan because motive yang menunjukkan pada masa lalu (Lailiyah, 2015). Sebagai gambaran penjelasan tersebut, Alferd Schutz memberikan contoh sebagai berikut. Apabila individu menggunakan payung ketika hujan maka, in order to motive berbentuk pernyataan seperti untuk menjaga baju agar tidak terkena air hujan. Berbeda dengan motif kedua yaitu because motive, didasarkan pada pengalaman dan pengetahuan yang didapatkan sebelumnya. Tentang bagaimana menggunakan payung agar baju tidak basah saat hujan (Selatan et al., 2019). Artinya, setiap individu memiliki motif tersendiri dalam melakukan tindakan 


\section{METODE}

Penelitian ini menggunakan teknik kualitatif deskriptif yang didasarkan pada empirisme atas gejala sosial yang ada (Sadewo, 2004). Oleh karena itu, kualitatif lebih menakankan pada kenyataan yang sebenarnya saat di lapangan. Penelitian ini di lakukan di Gresik kota Santri tepatnya di Menganti. Subyek dalam penelitian ini adalah para santriwan dan santriwati legal serta memiliki hak suara penuh pada pilpres 2019. Teknik observasi untuk mengamati kondisi lapangan dan objek yang akan diteliti secara sistematis. Berikutnya, teknik wawancara secara langsung dengan informan untuk memperoleh data. Terakhir, dokumentasi sebagai pelengkap data untuk memperoleh bukti penelitian yang berdasarkan fakta di lapangan. Di sisi lain, teknik analisis data dalam penelitian ini bersifat induktif berawal dari proses mencari dan menyusun data secara sistematis. Di dapatkan dari hasil wawancara, field note, dan dokumentasi. Selanjutnya yaitu mengelompokkan data kedalam suatu kategori serta menganalisisnya. Berikutnya adalah reduksi data yang dilakukan dengan cara membuat abstraksi. Kedua, penyajian data dilakukan untuk menyesuaikan data dengan fokus permasalahan penelitian. Hasil data tersebut dituangkan kedalam field note, kemudian peneliti mengedit data yang berkaitan dengan fokus penelitian. Ketiga, penarikan kesimpulan terkait dengan perubahan pilihan santri Gresik pada pilpres 2019 kandidat pasangan Jokowi versus Prabowo.

\section{HASIL DAN PEMBAHASAN}

Pemilihan presiden 2019 memiliki isu-isu yang hangat diperbincangkan oleh publik. Salah satunya adalah timses Jokowi yang menggandeng Ma'ruf Amin sebagai wakil presiden. Seperti yang diketahui bersama bahwa ormas Islam di Indonesia dapat dikatakan memberikan sumbangan besar dalam mendulang suara. Hal tersebut tentu dimanfaatkan oleh kelompok-kelompok yang memiliki kepentingan. Berkaitan dengan hal tersebut masyarakat termasuk para santri di Gresik banyak yang berpendapat bahwa Ma'ruf Amin sebagai wakil presiden adalah sebagai strategi politik. Hal tersebut dikarenakan ia merupakan ulama' besar NU dan memiliki kedekatan emosional dengan kiai lain di Indonesia. Oleh karena itu, pesantren dengan para santriwan dan santriwati didalamnya menjadi target untuk melakukan kampanye. Hal tersebut dilakukan agar mereka memiliki keberpihakan terhadap calon presiden. Berkaitan dengan hal tersebut, diwilayah yang terkenal dengan kota Santrinya seperti Gresik mengalami perubahan suara pada pilpres 2019. Hal tersebut tentunya didukung oleh dominasi suara para santri yang ada di Gresik.

Motif para santri memilih paslon Jokowi Ma'ruf Amin pada pilpres 2019 sangat beragam dari setiap individu. Motif tersebut dari adanya pengaruh manusia hingga kuasa Sang Pencipta. Berkaitan dengan hal tersebut beberapa santri yang ada di pesantren Gresik memaparkan pendapatnya bahwa, mereka memiliki kepercayaan yang tinggi terhadap paslon Jokowi Ma'ruf. Hal tersebut dikarenakan kredibilitas keduanya yang sudah tidak diragukan lagi. Terlihat dari Jokowi yang sering melakukan blusukan terhadap rakyatrakyat kecil. Tindakan kecil semacam itu dapat terbukti menarik simpati para santri karena, mereka beranggapan bahwa pemimpin tersebut sangat merakyat. Di samping itu, juga memperhatikan keadaan orang-orang kelas menengah ke bawah. Begitu pula, sosok Ma'ruf Amin juga sering melakukan blusukan seperti di Petrokimia Gresik. Banyak masyarakat dan para santri yang datang karena, ingin bertemu dengan Ma'ruf Amin. Selain itu, mereka juga ingin mendengarkan secara langsung program kerja Jokowi - Ma'ruf Amin apabila terpilih nanti. Para santri juga ingin bertemu dengan idolanya yang selama ini hanya bisa dilihat melalui televisi atau you tube. Tidak, hanya itu, sosok Ma'ruf Amin juga dilirik oleh para santri karena, diharapkan mampu meningkatkan kualitas sarana dan prasarana pesantren untuk kegiatan pembelajaran. Di sisi lain, sebagai santri Nahdliyin 
mereka memiliki kepatuhan terhadap kiainya seperti tradisi yang ada dalam pondok pesantren. Para kiai biasanya memberikan stimulus untuk para santri agar memilih kandidat presiden tertentu. Terlihat dari praktik yang dilakukan para kiai menyampaikan unsur-unsur politik melalui tausiah dalam pondok pesantren (Anugrah, 2019). Hal tersebut jelas mempengaruhi pilihan para santri. Terutama para santri yang baru saja mendapatkan hak suaranya. Mereka menganggap bahwa pilihan dari kiainya adalah pilihannya dan diharapkan dapat membawa dampak yang baik. Di samping itu, para santri juga menjelaskan bahwa motif mereka dalam memilih presiden dan wakilnya karena, terinspirasi oleh kiai dan Ma'ruf Amin. Hal tersebut dikarenakan banyaknya ilmu dan pengalaman yang mereka dapatkan dari sosok tersebut. Tentunya ilmu yang mereka dapatkan tidak hanya ilmu science saja namun, juga ilmu agama. Oleh karena itu, para santri berharap bahwa ilmu itu dapat bermanfaat untuk diri sendiri dan orang lain.

Sebenarnya, para santri menyadari bahwa pemilihan Ma'ruf Amin sebagai wakil presiden yang diusung oleh timses Jokowi adalah taktik politik. Oleh karena itu, kelompok agama dari setiap individu dapat mempengaruhi pilihan. Namun, bukan berarti menjadi alasan dalam sebuah perpecahan. Lebih dari itu, dengan adanya setiap perbedaan baik agama, ras, suku, dan lain sebagainya harus bisa meningkatkan persatuan. Persatuan tersebut tentunya dapat dipupuk melalui rasa toleransi dan kerja sama seluruh elemen masyarakat. Hal tersebut dikarenakan, perbedaan adalah semua warna dan kekayaan yang dimiliki setiap wilayah termasuk Indonesia. Berkaitan dengan hal tersebut, sebenarnya para santri juga tidak berpatokan pada background dari calon kandidat presiden dan wakilnya. Tetapi, pada kualitas setiap masing-masing pasangan calon presiden. Para santri dalam hal ini, yakin setiap kandidat memiliki kualitas namun, mereka juga memilih sesuai dengan hati nurani. Di samping itu, mereka memiliki pengetahuan dan pengalaman yang berbeda tanpa harus menjelekkan paslon lain yang bukan pilihannya. Para santri juga mengatakan bahwa Jokowi-Ma'ruf Amin dianggap bisa bertanggung dan membawa Indonesia lebih sejahtera. Di samping itu, para santri juga menganggap bahwa kemenangan Jokowi - Ma'ruf adalah kuasa dari Tuhan. Terlepas dari kemenangan Jokowi dan Ma'ruf Amin, sebenarnya para santri juga akan menerima siapapun yang terpilih menjadi presiden dan wakilnya. Mereka akan mendoakan agar presiden dan wakil presiden semoga bisa mengemban amanah dan membawa Indonesia ke arah yang lebih baik.

Berkaitan dengan hasil penelitian tersebut jika dikaitkan dengan teori Alfred Schutz maka, terdapat motif sebab dan motif tujuan santri dalam memilih kandidat pasangan presiden dan wakilnya. Seperti yang kita ketahui bersama bahwa kandidat presiden dan wakilnya dalam pilpres 2019 yaitu Jokowi-Ma'ruf dan Prabowo-Sandiaga Uno. Mereka dan timses melakukan berbagai taktik dan strategi untuk memperoleh kemenangan. Disamping itu masyarakat termasuk para santri memiliki hak masing-masing untuk memilih. Tentunya dalam memilih kandidat presiden dan wakilnya itu ada motif didalamnya. Tidak jarang pula santri melakukan pembelaan kepada pasangan calon yang dipilihnya walaupun diterpa berbagai isu negatif yang menghampiri paslon tersebut. Jika dikaitkan dengan perspektif teori in order to motive Alfred Schutz maka, para santri berharap Jokowi-Ma'ruf dapat membawa Indonesia lebih maju lagi dengan melihat kualitas keduanya. Bukan berarti mereka menjatuhkan paslon dari lawan Jokowi - Ma'ruf. Para santri tentu akan menerima dan mendoakan siapapun yang menang dalam pilpres 2019 tersebut. Disamping itu, jika menggunakan because motive maka, terdapat berbagai alasan yang mendasari untuk tidak memilih paslon lain. Salah satunya karena, kredibilitas dari Jokowi Ma'ruf yang tidak memiliki riwayat korupsi. Di samping itu, juga memiliki jiwa kepemimpinan dengan berbagai pengalaman yang dimiliki. Oleh karena itu, para santri 
memiliki kepercayaan yang tinggi terhadap Jokowi Ma'ruf Amin. Bukan hanya background dalam dirinya tetapi, kualitas yang dimilikinya.

\section{KESIMPULAN}

Berdasarkan hasil penelitian dan pembahasan diatas menunjukkan motif, motif perubahan pilihan santri Gresik sangat beragam. Salah satunya dikarenakan, kualitas dari Jokowi - Ma'ruf Amin. Para santri berharap Jokowi - Ma'ruf mampu membawa Indonesia kearah yang lebih baik. Namun, terdapat pula yang setuju jika kemenangan Jokowi pada pilpres 2019, tidak terlepas dari peran Ma'ruf Amin sebagai ulama. Seperti yang diketahui bersama bahwa Ma'ruf Amin memiliki background sebagai ulama terkemuka. Oleh karena itu, Ma'ruf juga memiliki kedekatan emosional dengan kiai besar di seluruh Indonesia. Di sisi lain, santri sebagai warga Nahdliyin memiliki kepatuhan terhadap kiai seperti tradisi pondok pesantren. Di samping itu, juga adanya kuasa dari Tuhan yang dapat menentukan pemimpin negara untuk periode selanjutnya. Pilpres pada tahun 2019 kemarin merupakan demokrasi yang menjadi sorotan publik. Masing-masing kandidat presiden dan wakilnya memiliki cara tersendiri untuk menarik suara dan simpati masyarakat termasuk para santri.

\section{DAFTAR RUJUKAN}

Abidin, M. H. (2018). Pembentukan identitas santri dalam politik. Faculty of Sociology and the Humantities, 2, 271-292.

Anugrah, Y. dan A. M. (2019). Hegemoni Kyai Terhadap Santri.

Aziz, N. (2018, September 22). Strategi Jokowi dan Prabowo untuk pilpres 2019, dari ekonomi, SARA sampai ke medsos. NEWS / Indonesia. https://www.bbc.com/indonesia/indonesia-45605038

Ernas, S. (2005). Dampak Keterlibatan Pesantren dalam Politik: Studi Kasus Pesantren di Yogyakarta. 25(2), 0-1.

Fauzi Agus. (2019). Perilaku Pemilih Menjelang Pemilu 2019. Islamic Civilization, 1, 42.

Hidayat, E. (2014). Hubungan Kiai dan Politik: Peran Politik Kiai Pada Pilpres 2014 di Pesantren Areng- Areng Pasuruan Jawa Timur. SSRN Electronic Journal, 5(564), 119. https://doi.org/10.4324/9781315853178

Hidayat, E. (2016). Peran Kiai Pada Pemilihan Presiden Tahun 2014 di Pesantren ArengAreng Pasuruan Jawa Timur.

Lailiyah, A. N. (2015). Motif Sebab dan Tujuan. Paradigma, Volume 03, 1-8.

Sadewo, F. S. (2004). Petunjuk Praktis Untuk Peneliti Pemula.

Santoso, M. A. (2013). Perkembangan Konstitusi Di Indonesia. Yustisia Jurnal Hukum, 2(3). https://doi.org/10.20961/yustisia.v2i3.10168

Selatan, D. I. S., Muhaimin, A., \& Ginting, E. (2019). Motif Pemilih Muslim dalam Memilih Calon Presiden 2019-2024 ( Studi Fenomenologi dalam Kontestasi Pemilihan Presiden ). 19(2), 60-69.

Susilo, D., \& Roesli, M. (2018). Konsep Pemerintahan Indonesia Menurut UUD 1945. Mimbar Yustitia: Jurnal Hukum Dan Hak Asasi Manusia, 2(1), 112-129. http://ejurnal.unisda.ac.id/index.php/mimbar/article/view/1385

Ulzikri, A. R. (2019). Politik Nahdlatul Ulama dalam Pemilihan Presiden dan Wakil Presiden 2019. SSRN Electronic Journal, 5(564), 1-19. https://doi.org/10.4324/9781315853178

Wulandari, I. (2017). Analisis Pemilihan Presiden dan Wakil Presiden di Indonesia dalam Perspektif Hukum Islam. 3(1), https://doi.org/10.1017/CB09781107415324.004 